УДК 519.8:336.02

DOI: 10.18523/2519-4739.20205.1.95-100

O. Nezhyvenko

\title{
UNDECLARED WORK IN UKRAINE: EVIDENCE FROM THE 2020 STUDENT SURVEY
}

This paper presents the results of the first of its kind survey on the undeclared work in Ukraine, performed by the students of the National University of Kyiv-Mohyla Academy. This is a pilot study based on 133 observations collected in March-April of 2020 in Ukraine. The sample mostly consists of young individuals residing in urban areas, single, without children, and more females as compared to males. To work undeclared means to have any paid activities that are lawful but not declared to the public authorities. The paper discusses who works undeclared in Ukraine, the educational attainment, the employment status and the economic activity of undeclared workers. Almost half of the respondents estimate the share of the population of Ukraine who perform undeclared work at the level of 43 per cent. Almost all admit knowing other undeclared workers. The risk of being detected for undeclared work is perceived to be low by almost half of the interviewees. The most popular undeclared activities are tutoring, sales, marketing, working as a waiter/waitress, an analyst, an employee in consultancy and construction. The income from formal work is observed to be lower than from undeclared work. The mean net income for formal work is under UAH 5,000 per month, while the mean net income for undeclared work is between UAH 5,000-10,000. The most common reasons for performing undeclared work are willingness to earn more, easiness to find a job, and avoiding paying taxes. Finally, the paper presents the list of recommendations to tackle the undeclared work in Ukraine, the most popular of which were as follow: to reduce the income tax, to increase fines for undeclared work, to introduce penalties for undeclared work not only for employers but also to employees, to strengthen administrative responsibility of employers, and to ease the tax system.

Keywords: undeclared work, labour market, informal employment, Ukraine.

\section{JEL classification: E26, J46}

Introduction and research problem. Undeclared work is of concern for countries, governments, and individuals because for rational economic agents in the long-run period its payoff is smaller than the gain. To work undeclared means to have at least one paid work activity that is not declared to public authorities, to say it simply, taxes are not paid, or the business is not officially registered, or part of the salary is paid in the envelope. Undeclared work is defined as "any paid activities that are lawful as regards their nature but not declared to the public authorities, taking into account the differences in the regulatory systems of the countries" (Williams et al., 2017).

This definition encapsulated the undeclared work (ILO, 2018):

- at formal enterprise, or what could be referred to as undeclared paid employment, where the work could be undeclared in full or in part, and, accordingly, full or a part of wage is paid 'in envelopes';

- as an own-account worker, or employer in favour of formal enterprise or household including work without pay;
- as an own-account worker, or collectively with the neighbours, friends or acquaintances (other close social groups) to deliver goods and services to final consumers.

Description of the sample. The sample consists of 133 observations. Because the interviews were conducted in March-April of 2020 during the quarantine, most of them were conducted online.

The only requirements for individuals to be interviewed were to have undeclared activities and represent different economic activities. Respondents were selected by the students (interviewers) from their acquaintances. That is why, together with size, the collected sample is not representative of the Ukrainian adult population but is focused on the undeclared workers.

Recent publications analysis. There is a vast literature to analyse the undeclared work in the European Union, in terms of defining it (European Commission, 1998; European Parliament, 2008), its role in economic development of countries (European Commission, 2007; Williams \& Horodnic, 2017b) and ways to tackle it (Williams \& Horodnic, 2017a; Williams \& Renooy, 2013). 
The International Labour Organization recognizes undeclared work as a "social dumping" that distorts competition and states that all European institutions lack the consistency in defining "undeclared work" (ILO, 2010; Robert, 2011).

Only several papers in Ukraine address this issue in our country. The International Labour Organization focused on undeclared work in Ukraine and tackles recommendations to diminish the scope of this phenomenon in Ukraine (ILO, 2018). Nezhyvenko and Shumska (2018) provide a descriptive study of the Ukrainian Undeclared Work Survey from 2017. Nezhyvenko (2018) compares the perception of undeclared work in Ukraine and in the European Union. These publications conclude that undeclared work in Ukraine is an obstacle for the development of the local labour market and stress on the importance to study it further. Hence, the current paper aims to contribute to this literature by providing a glance on the undeclared work in Ukraine in 2020.

Research goal and questions. The paper presents the main findings of the sample of the undeclared workers in Ukraine interviewed during March-April of 2020. The research questions include:
Description of the sample. In the sample, there are 60 per cent of females and 40 per cent of males. Most individuals $(94 \%)$ reside in urban areas. The age of interviewees ranges from 17 to 70 with the average age of 26 and the median age of 20 . The majority of individuals in the sample $(67 \%)$ are not in a relationship. Most of them (76\%) do not have children, 16 individuals have one child, 14 individuals $=$ two children and two individuals = three children. Hence, the sample is young, living in cities, single, without children and consists mostly of females. The educational attainment of the sample is portrayed below in Fig. 1.

Overall, 63 per cent of respondents are currently at university, on fifth of them (24\%) already graduated from the university and 12 per cent have only secondary education.

Regarding employment status, most of them being one-third $(27 \%)$ consider themselves unemployed (it is worth noting that self-perception of employment is not in line with the ILO definition of unemployment). Full-time employees are 22 per cent and every fifth $(20 \%)$ is a part-time employee. Only 10 per cent are self-employed. Interestingly, 21 per cent of respondents are registered as

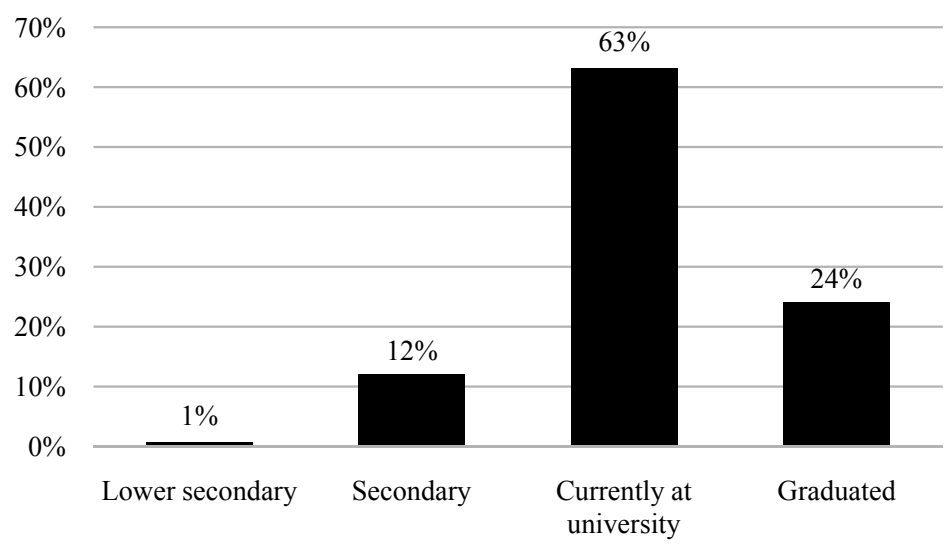

Fig. 1. Educational attainment of the respondents

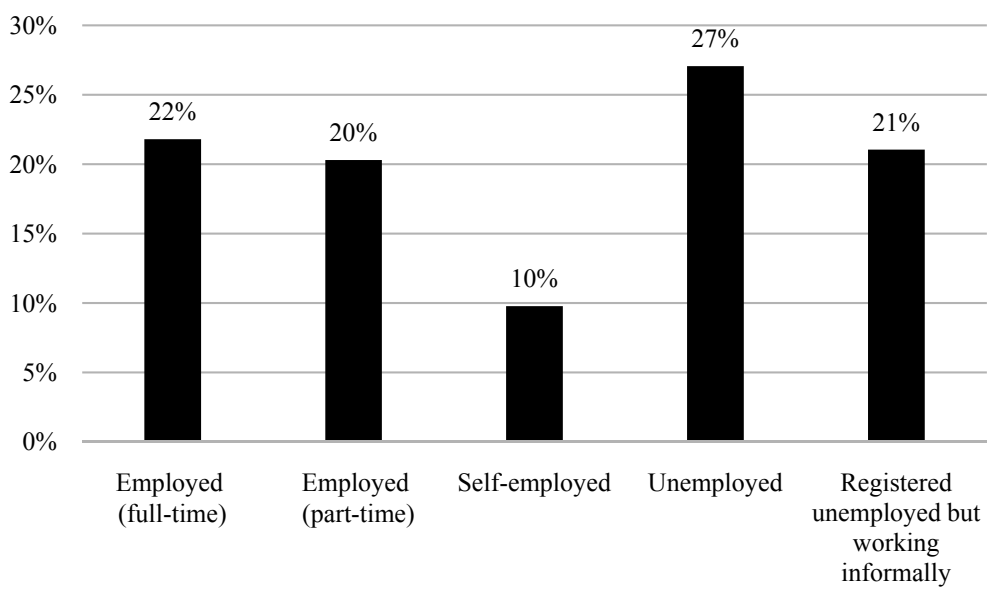

Fig. 2. Employment status of the respondents 
unemployed but at the same time admit working undeclared (see Fig. 2).

The interviewees were also asked about the sector they work in. The most popular kinds of activities performed by them are marketing, tutoring, retail, IT, personal care services (manicure, hairdresser) and working in hotels, restaurants and cafes.

Main findings. Respondents were asked to evaluate the share of the population of Ukraine that has work activity, which is not officially registered, or do not pay taxes. The overall sample mean is 43 per cent. The distribution of answers is reported in Fig. 3.

One third of the sample ( $29 \%$ ) believe the share of undeclared work in Ukraine is between 15-30 per cent of workers. The same share (29\%) estimate the share of undeclared work at the higher level of $31-45$ per cent of the workers. One fifth of the sample $(21 \%)$ think that the share of undeclared work reaches 46-60 per cent of workers. Slightly less $(17 \%)$ evaluate this share between $61-75 \%$ of workers. There were two interviewees $(4 \%)$ who assume the share of undeclared workers amounts to 76-90 per cent of workers.
Another question asked if respondents personally know anyone who has work activity that is not officially registered, or does not pay taxes. Almost all respondents (130 or $98 \%$ ) admit knowing undeclared workers. At the same time, this question may be biased because the sample was not planned to be representative. Consequently, undeclared workers should know other undeclared workers that may be their colleagues.

The risk of being detected for undeclared work by controlling institutions was described as low by almost half of respondents (44\%). Every third individual $(28 \%)$ believes the risk is medium and every fourth $(25 \%)$ that it is very low. Those who regard this risk as high and very high constitute only 4 per cent of the sample.

Besides sector, respondents also described activities they performed as undeclared workers in the twelve months preceding the interview. The most popular activity were: tutoring (28 answers), sales, retail or trading (21), marketing and advertising (8), waiting tables (7), work as an analyst (6), consultant (4), in construction (4), doing manicure (4), writing papers (3), cooking (3) and

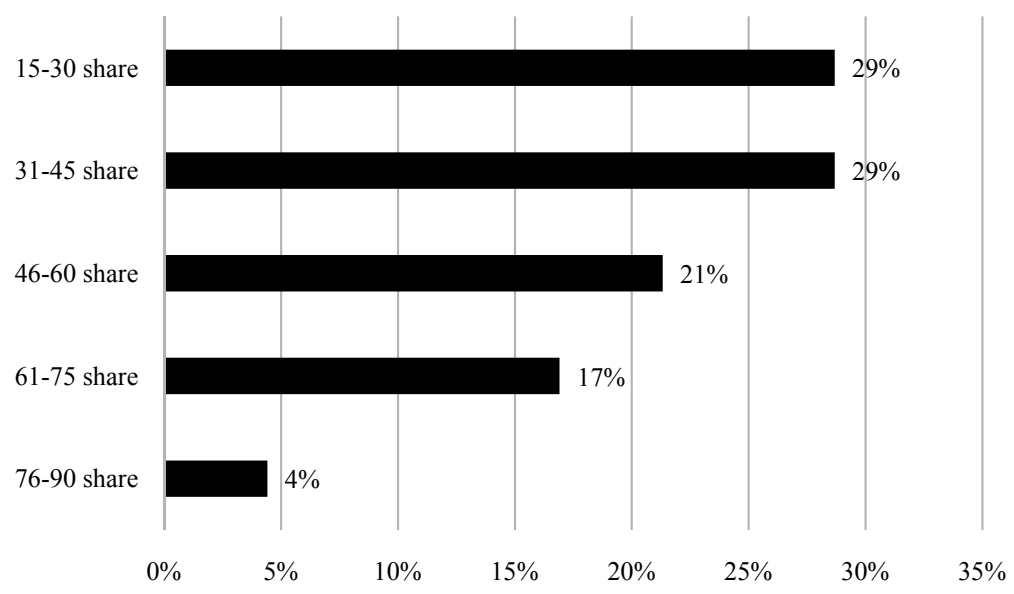

Fig. 3. Estimate of the share of undeclared work in Ukraine by interviewees

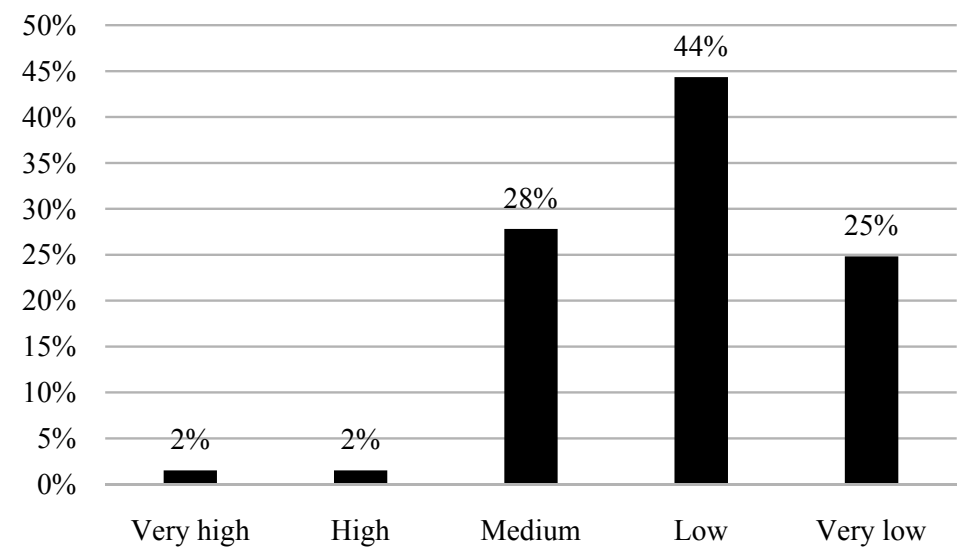

Fig. 4. Estimate of the risk of being detected for undeclared work 
babysitting (3). Among the most qualified activities are also pre-election campaigning in a political party, research, work with legal documents, managing social media, work as a cosmetologist and an accountant. Also respondents mentioned to have worked as a veterinary doctor, a skating instructor, a photographer, doing modelling, car washing, running Instagram courses, scientific experiments, tailoring, and even working as a casino dealer (which is not legal at the time of the interviews).

The respondents were asked to describe their net income generated from formal work (see Fig. 5) and undeclared work (see Fig. 6) during the last month.

The sample average for the net income generated from formal work was at the level not more than UAH 5,000. According to Fig. 5, most individuals $(37 \%)$ have an income level up to UAH 5,000. Only 3 per cent of respondents earn above UAH 20,000.

The sample average for the net income generated from undeclared work was UAH 6,600 on average. According to Fig. 6, most individuals (35\%) have an income level between 5,000 and UAH 10,000, one fourth $(25 \%)$ - below UAH 5,000. An income above UAH 20,000 is earned by 12 per cent of interviewees.

Among the main reasons for participating in undeclared work, the three most often cited are the willingness to receive higher income when working undeclared, ease of finding a job, and avoiding paying taxes (especially if income is not enough to cover a minimum tax). Quite many answered that undeclared work arrangement was an employer's requirement. Other reasons named were high level of taxes, complicated registration as a self-employed (and exit from official registration), no (or very low) risk of punishment and no control from the government. Many respondents also mentioned non-willing to contribute money to "fraudulent" government authorities, low trust to government, someone even replied: "I think taxes I will pay will fade away". Some respondents admit having had negative formal work experience and complicated procedures to be hired formally. For many, undeclared work was a temporary source of income

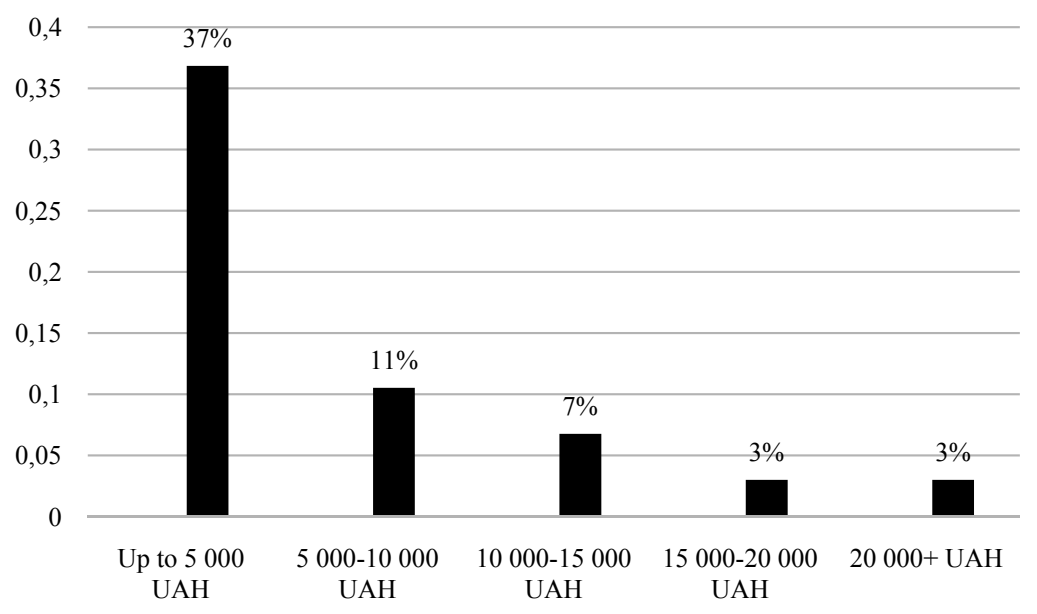

Fig. 5. Monthly income generated from formal work

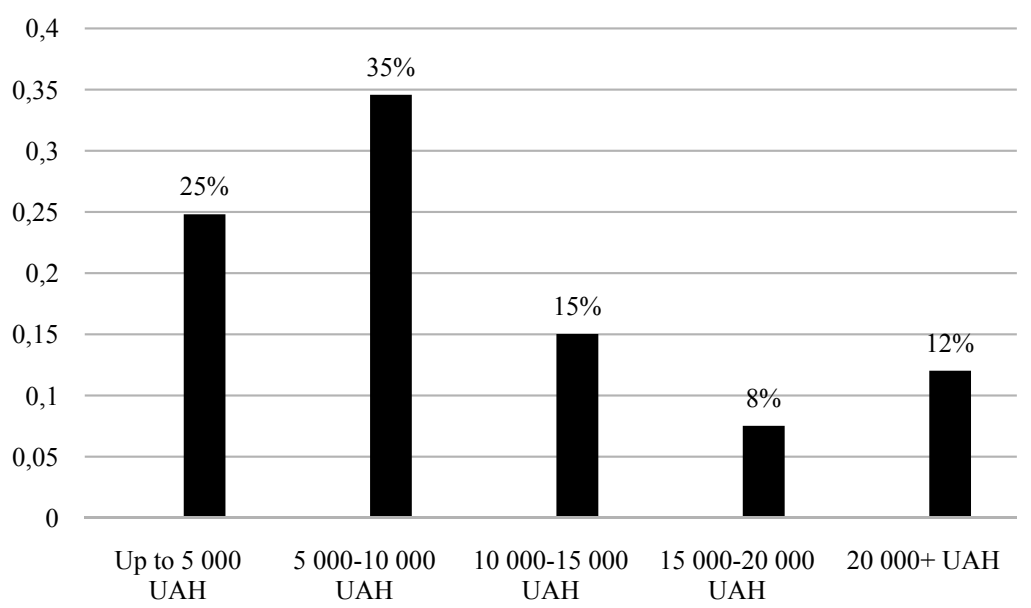

Fig. 6. Monthly income generated from undeclared work 
("it does not make sense to formalize it as the income is relatively low even without paying tax"), provided a flexible schedule, or was a safety net besides formal employment. For some, "the type of job is a higher priority rather than a formal contract." One respondent even said that "an unofficial salary can be received by a person who has a poor mind." Finally, another reason to have undeclared work was to gain from subsidies for utilities and public benefits to the registered unemployed.

As a final point, respondents proposed recommendations how undeclared work in Ukraine may be reduced. The mentioned policy measures (sometimes conflicting) included:

- to reduce the income tax;

- to increase fines for undeclared work;

- to introduce penalties for undeclared work not only for employers but also to employees ("financial penalties should be proportional to undeclared earnings");

- to strengthen administrative responsibility of employers for using undeclared work;

- to ease the tax system and make is more "citizen-friendly";

- to explain how the fiscal system works and how taxes should be paid;

- to increase the minimum wage;

- to increase the number of labour inspectors ("according to the legislation, a sole proprietor can have less than 10 workers, but many restaurants in Kyiv have more employees. Therefore, at least some of those workers are working undeclared");

- to diminish the frequency of any kind of inspections and to decrease the number of controlling institutions;

- to introduce an information campaign such as explaining the causes and the consequences of informal economy, promoting declared work and explaining why it is important to pay taxes;

- in general, to raise trust to the government by showing the citizens what their taxes are spent on and educate what the tax payers' money are spent on;

- to provide more benefits for small businesses, such as lower interest rates.

Conclusions and further research proposals. This paper reports the results of the first of its kind survey on the undeclared work in Ukraine performed by the students. The survey that is based on the sample of 133 observations collected in
March-April of 2020 suggest that the majority of Ukrainian undeclared workers are young females, living in cities, single and without children. They either study at the university or graduated. Onethird of undeclared workers consider themselves unemployed, equally represented are full-time and part-time employees, and one-fifth of the sample are registered unemployed.

Almost half of respondents estimate the share of the population of Ukraine that perform undeclared work at the level of 43 per cent. Almost all admit knowing other undeclared workers. The risk of being detected for the undeclared work is perceived to be low. The most popular undeclared activities are tutoring, sales, marketing, working as a waiter/ waitress, an analyst, working in consultancy and construction. The mean income for formal work is under UAH 5,000 per month, while the mean income for undeclared work is between UAH 5,00010,000 . The most common reasons for performing undeclared work are willingness to earn more, easiness to find a job, and avoiding paying taxes. Finally, the list of recommendations to tackle the undeclared work in Ukraine include but are not limited to improving the tax system, increasing penalties for the undeclared work, strengthening the administrative responsibility of employers, improving labour inspection, and running an information campaign to raise trust to the government and explain the importance of paying taxes. In the work in progress, the perception of the undeclared work in Ukraine is tackled and the recommendations to decrease it are enlarged.

Acknowledgement. The author of the paper expresses gratitude to the student group of Informal Economy and Financial Development course 2020 at the National University of Kyiv-Mohyla Academy for contributing to this paper by collecting data and analysing it under the course assignment. The 28 students who contributed to this research are: Adamska Polina, Bykovska Maria, Demura Ivan, Fedoriv Oleksandr, Golovatskyi Svyatoslav, Hanina Kateryna, Hrechany Petro, Kalyniv Zoriana, Kermach Ihor, Khmelovska Hanna, Klimchenko Vladyslav, Mordas Olena, Nazaruk Oleksandr, Nedozhdii Mykhailo, Novikova Anastasiya, Novotarska Valeriia, Novotarska Yevheniia, Palamarchuk Bohdana, Savchyn Mykola, Sobol Danylo-Myroslav, Stepanenko Yevhenii, Strukov Maksym, Subtelnyi Mykola, Supyk Yuliya, Surovets Viktoriia, Taraday Alexander, Vaskivska Nataliia and Zadorozhnia Kateryna. 


\section{References}

European Commission. (1998). Communication from the Commission on undeclared work. Brussels: European Commission. Office for Official Publications of the European Communities.

European Commission. (2007). Stepping up the fight against undeclared work. Brussels: Commission of the European Communities.

European Parliament. (2008). Stepping up the fight against undeclared work. European Parliament resolution of 9 October 2008 on stepping up the fight against undeclared work (2008/2035(INI)).

ILO. (2010). Labour inspection in Europe: undeclared work, migration, trafficking. Geneva: International Labour Office.

ILO. (2018). Undeclared Work in Ukraine: Nature, Scope and Measures to Tackle It (EU-ILO Project "Enhancing the Labour Administration Capacity to Improve Working Conditions and Tackle Undeclared Work"). Kyiv.

Nezhyvenko, O. (2018). Wahrnehmung und Akzeptanz von Schwarzarbeit in der Ukraine und in der Europäischen Union [Perception and acceptance of undeclared work in Ukraine and in the European Union]. Ukraine-Analysen, 206, 8-14. http://www. laender-analysen.de/ukraine/pdf/UkraineAnalysen206.pdf
Nezhyvenko, O., \& Shumska, S. (2018). Ukrainian Undeclared Work Survey: First Findings. Scientific Papers NaUKMA. Economics, 3(1), 89-94. https://doi.org/10.18523/25194739312018150626

Robert, R. (2011). Defining Undeclared Work in Europe. Labour Administration and Inspection Programme. LAB/ADMIN. Geneva: International Labour Office.

Williams, C. C., Bejakovich, P., Mikulic, D., Franic, J., Kedir, A. M., \& Horodnic, I. A. (2017). An evaluation of the scale of undeclared work in the European Union and its structural determinants. estimates using the labour input method. European Commission.

Williams, C. C., \& Horodnic, I. A. (2017a). Evaluating the policy approaches for tackling undeclared work in the European Union. Environment and Planning C: Politics and Space, 35(5), 916-936. https://doi.org/10.1177/0263774X16670665

Williams, C. C., \& Horodnic, I. A. (2017b). Under-Declaring Work Falsely Declaring Work: Under-Declared Employment in the European Union. European Platform Undeclared Work Report.

Williams, C. C., \& Renooy, P. (2013). Tackling Undeclared Work in 27 European Union Member States and Norway. Approaches and Measures since 2008. Dublin.

Неживенко О. В.

\section{НЕЗАДЕКЛАРОВАНА ПРАЦЯ В УКРАЇНІ: РЕЗУЛЬТАТИ ОПИТУВАННЯ СТУДЕНТІВ 2020 РОКУ}

У статті подано результати першого такого опитування щодо незадекларованої праці в Україні, яке провели студенти Національного університету «Києво-Могилянська академія». Це пілотне дослідження, яке базується на 133 спостереженнях, зібраних з березня по квітень 2020 р. в Україні. Вибірка складається переважно з молодих індивідів, які проживають у міській місцевості, одиноких, без дітей, до того ж жінок більше, ніж чоловіків. Незадекларована праця - це будь-яка оплачувана діяльність, яка $є$ законною, але не задекларованою в державних органах. У статті проаналізовано характеристики працівників незадекларованої діяльності, а саме: хто працює незадекларовано, їхній рівень освіти, статус зайнятості та економічна активність. Майже половина респондентів оцінюють частку населення України, яке виконує незадекларовану роботу, на рівні 43 \%. Майже всі опитані зізнаються, що знають осіб, які є незадекларованими працівниками. Ризик виявлення незадекларованих працівників вважають низьким майже половина опитаних. Найпопулярнішими незадекларованими видами діяльності $\epsilon$ репетиторство, торгівля, маркетинг, робота офіціантом/офіціанткою, аналітика, надання консультативних послуг та будівництво. Дохід від офіційної роботи визначено як нижчий, ніж від незадекларованої. Згідно з даними опитування, середній чистий заробіток за офіційну роботу становить менше ніж 5000 грн на місяць, тоді як за незадекларовану роботу - від 5000-10 000 грн. Найпоширенішими причинами участі в незадекларованій праці є бажання отримувати вищий дохід, легкість пошуку роботи та уникнення сплати податків. Також у статті наведено перелік рекомендацій щодо подолання незадекларованої роботи в Україні, найпопулярнішими з яких були, зокрема, такі: зменшити податок на прибуток, збільшити штрафи за незадекларовану роботу, запровадити штрафні санкції за незадекларовану роботу не тільки для роботодавців, але й для працівників, посилити адміністративну відповідальність роботодавців та спростити податкову систему.

Ключові слова: незадекларована праця, неформальна зайнятість, ринок праці, Україна.

Матеріал надійшов 30.04.2020

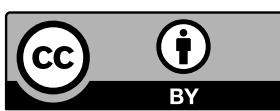

Creative Commons Attribution 4.0 International License (CC BY 4.0) 